\title{
A magyar önkormányzati eladósodás és válságkezelés nemzetközi összehasonlításban
}

\begin{abstract}
Tanulmányunk célja, hogy nemzetközi összehasonlításban mutassa be a magyar önkormányzati szektor eladósodását és válságkezelését. A hazai önkormányzatok pénzügyi válságának kialakulásához atipikus tényezők is hozzájárultak. Jó néhány önkormányzat spekulatív céllal vett fel alacsony kamatozású devizahiteleket, s ezekkel gyakorlatilag úgynevezett carry trade ügyletekbe fogott. A nem kellően átgondolt központi fejlesztési támogatások szintén gyengítették az önkormányzatok pénzügyi stabilitását. A magyar önkormányzati konszolidáció a rendkívüli költségvetési támogatás mellett nemzetközi összehasonlításban újszerü eljárásokat is tartalmazott. A nemzetközi tapasztalatokkal összhangban a központi pénzügyi segítségnyújtás Magyarországon is együtt járt a központi költségvetési ellenőrzés erősítésével.*

Journal of Economic Literature (JEL) kódok: E62, H12, H74.
\end{abstract}

Az államháztartás központi alrendszerének eladósodása mellett a regionális és helyi önkormányzatok eladósodása is gyakori jelenséggé vált a világban. Még konzervatív és körültekintő hitelfelvétel esetében is elöfordulhatnak olyan események, amelyek fenntarthatatlanná teszik a nagy adósságállományt. A helyi önkormányzatok és régiók túlzott eladósodása jelentős kockázatot hordoz, mert ellehetetlenítheti az állam müködését, ami nagymértékben kihathat a lakosság életminőségére. Ugyanis a helyhatóságok által nyújtott közszolgáltatások esetleges ellehetetlenülése jelentős politikai és jogi kockázatokat hordoz: sérülhet a közszolgáltatásokhoz való egyenlö hozzáférés joga. Így a „túl nagy ahhoz, hogy csődbe mehessen” (too big to fail) problémához hasonló, de eltérő tartalmú jelenséget tapasztalhatunk, amelyet a „túl érzékeny ahhoz, hogy csődbe mehessen” (too sensitive to fail) vagy „túl állami ahhoz, hogy csődbe mehessen”

* Köszönjük az anonim lektorok hasznos észrevételeit, a fennmaradó hibákért bennünket terhel a felelösség.

Bethlendi András docens, BME GTK Pénzügyek Tanszék (e-mail: bethlendi@finance.bme.hu).

Lentner Csaba egyetemi tanár, NKE ÁKK Közpénzügyi Kutatóintézet (e-mail: dr.lentnercsaba@ gmail.com).

A kézirat első változata 2019. február 14-én érkezett szerkesztőségünkbe.

DOI: http://dx.doi.org/10.18414/KSZ.2019.10.1013 
(too national to fail) problémaként írhatunk le. Ez a jelenség a „túl nagy ahhoz, hogy csődbe mehessen" problémához hasonlóan morális kockázatot okoz: felelőtlen gazdálkodásra ösztönözhet helyi szinten, mert a központi kormányzat egy ponton túl úgyis megmenti az adott regionális vagy helyi önkormányzatot.

Tanulmányunkban először összefoglaljuk az önkormányzati eladósodás kialakulása és kezelése terén eddig felhalmozódott nemzetközi tapasztalatokat, majd ennek alapján áttekintjük a magyar önkormányzati szektor eladósodását és konszolidációját. Feltárjuk azokat a tényezőket, amelyek atipikussá tették a magyar önkormányzati válságot és kezelésének módját. Tanulmányunkat összefoglaló megállapításokkal zárjuk.

\section{Miért adósodnak el az önkormányzatok? Nemzetközi példák}

A költségvetési válság olyan helyzetként jellemezhető, amelyben az állam elveszíti a (további) piaci finanszírozás lehetőségét, vagy olyan növekvő finanszírozási költségekkel szembesül, amelyek ellehetetlenítik alapvető szolgáltatásainak nyújtását. A gyenge és romló hitelképesség sokszor együtt jár a kormányzat szavahihetőségének hiányával (Cordes és szerzőtársai [2015]). A költségvetési válság e definícióját alkalmazhatjuk regionális és helyi kormányzatokra is. ${ }^{1}$

Régiók és tartományok sokkal ritkábban mennek csődbe, mint szuverén államok. ${ }^{2}$ Sem az utóbbiak, sem az előbbiek esetében nincsen általánosan elfogadott csődeljárás. ${ }^{3}$ Ez a lól a legismertebb kivétel az Egyesült Âllamok gyakorlata, ahol az 1930-as évek óta több mint félezer csődvédelmi eljárást ${ }^{4}$ kezdeményeztek önkormányzatok (például a kaliforniai Orange és Jefferson megyék), városok (Detroit) és önkormányzati intézmények (iskolák, közüzemi cégek stb.) (Canuto-Liu [2010] és Liu-Waibel [2009]). Mivel ezek központi beavatkozást nem igényelnek, e válságkezeléseket nem tárgyaljuk.

A regionális és helyi költségvetési válságok okai között megkülönböztetjük a válságot közvetlenül kiváltó eseményeket a mélyebben meghúzódó (alapvető) okoktól. Tanulmányunkban az alapvető okokkal kívánunk foglalkozni.

A regionális és helyi költségvetési válsághoz vezető tényezőket két nagyobb csoportra bonthatjuk: központi és helyi tényezőkre.

${ }^{1}$ A külföldi szakirodalom a „szubnacionális” vagy a „szubszuverén” jelzővel illeti a szuverén állam alatti (azaz nem központi) államigazgatási szinteket, amelyek állami feladatokat látnak el, és még valamelyes döntési autonómiával rendelkeznek. A szintek száma (és autonómiájuk mértéke) országonként igen eltérő, ahogyan az elnevezésük is: (szövetségi/tag-) állam, tartomány, régió stb. Cikkünkben ezeket „regionális és helyi” szintnek, Magyarország esetében pedig leegyszerüsítve önkormányzati szintnek nevezzük.

${ }^{2}$ A csődöt úgy definiáljuk, hogy egy szuverén állam központi kormányzata vagy egy regionális, illetve helyi kormányzat valamely hitel típusú kötelezettségének nem vagy nem az eredeti feltételek mellett tesz eleget, és ebből a hitelezőknek kára származik. Az 1950 és 2010 közötti időszakban száznál is több államcsőd következett be (IMF [2013]).

${ }^{3}$ A szuverén adósságválságok ezért egyes esetekben nagyon elhúzódnak, bizonytalan kimenetelüek és költségesek (Bethlendi [2018]).

${ }^{4}$ A csődvédelmi eljárás olyan jogi mechanizmust biztosít, amelynek révén az önkormányzatok védelmet élvezhetnek hitelezőik fellépésével szemben annak érdekében, hogy meg tudjanak állapodni adósságuk átstrukturálásában. 


\section{A költségvetési válsághoz vezetö központi tényezök}

LIBERALIZÁCIÓ ÉS DEREGULÁCIÓ • Az eladósodás az önkormányzati szegmensben sem új keletủ jelenség. A közigazgatási és szabályozási változásokkal és a piaci liberalizációval az 1960-as és 1970-es években az önkormányzati hitelfelvétel különösen népszerűvé vált. Ugyanakkor számos központi kormányzat igyekezett szabályozni az ilyen hitelfelvételt azon felismerés alapján, hogy a piaci fegyelmező erö ${ }^{5}$ önmagában nem elegendő például információs problémák (kisebb entitások információs aszimmetriája, a transzparencia hiánya) és az erkölcsi kockázatok miatt. Ugyanakkor egyes szerzők amellett érvelnek, hogy a piaci fegyelmező erő müködhet ezen a piacon is, ha az önkormányzatok valóban nem számíthatnak központi kormányzati segítségnyújtásra, azaz a költségvetési korlátjuk kemény (Kornai [2014], Beck és szerzőtársai [2016]). A szakirodalom erre a helyzetre a „hiteles kormányzati segítségnyújtás nélküli rendszer" (credible no-bailout regime) kifejezést is használja. Megjegyezzük, hogy még konzervatív és körültekintő hitelfelvétel esetében is elöfordulhatnak olyan események, amelyek fenntarthatatlanná teszik az adósságállományt.

A regionális és helyi önkormányzatok gazdálkodására vonatkozó központi szabályozás és ellenőrzés fellazulása, illetve megszűnése a helyi eladósodás növekedéséhez és egyes esetekben túladósodáshoz vezet. Erre jó példa Ausztrália, ahol az egyes tagállamok hitelfelvételét és költségvetési folyamatait egy központi intézmény, a hiteltanács (Australian Loan Council) vezérelte, amely a pénz- és tőkepiacon felelősséget is vállalt az önkormányzatok adósságaiért. Ezen intézmény létrehozásának egyik fö célja egy hatékony adósságkezelő rendszer kialakítása volt. ${ }^{6}$ Ezt az intézményt több lépésben felpuhították, 1990-től pedig már teljes mértékben a tartományok feleltek az új adósságaikért. Ezzel együtt a szövetségi államok elindultak az eladósodás útján. Victoria állam már 1992-ben komoly finanszírozási gondokkal szembesült (Hagen és szerzőtársai [2000]).

Puha költségvetési korlát mellett a piaci fegyelmező erő hiányának egyik okát az úgynevezett kockázati transzfer hipotézise írja le, amely szerint a központi kimentésre vonatkozó piaci várakozások miatt az önkormányzatok finanszírozási költsége alacsonyabb és hitelhez való hozzáférése könnyebb lesz, mint azt saját hitelképességük indokolná. A másik oldalról viszont az önkormányzati alrendszer jelentősebb eladósodása megnövelheti az egész ország finanszírozási költségeit. ${ }^{7}$

ElÉgTELEN TRANSZPARENCIAKÖVETELMÉNYEK • Egyes feladataikat az önkormányzatok önálló intézményekkel is ellát(tat)hatják. Ez lehetővé teszi, hogy az önkormányzatok kikerüljék a hiányra és az eladósodásra vonatkozó korlátozásokat,

\footnotetext{
${ }^{5}$ A pénzügyi piacok nagyobb kockázati felárak felszámolásával büntetik a romló pénzügyi helyzetű regionális és helyi kormányzatokat, ezáltal kényszerítve őket nagyobb költségvetési fegyelemre.

${ }^{6}$ A nemzetközi tőkepiacon a szövetségi államok együttesen és egységesen lépjenek fel a hitelezőkkel szemben, ne egyenként.

${ }^{7}$ Jenkner-Lu [2014] spanyol adatokon igazolta a kockázati transzfer hipotézisét, nemzetközi mintán hasonló megállapításra jutott Beck és szerzőtársai [2016].
} 
illetve az itt keletkező adósságok rejtve maradjanak a központi kormányzat elől. Vicente Lama és szerzőtársai [2017] bemutatta, hogy a spanyol önkormányzati vállalkozások számviteli szabályai képesek voltak nagymértékben befolyásolni az önkormányzatok pénzügyi szabályoknak való megfelelését. A tanulmány szerzői megállapították, hogy az önkormányzatok tulajdonában álló vállalkozások alkalmasak a költségvetési hiány költségvetésen kívül helyezésére, ezzel rontva az önkormányzatok pénzügyi stabilitását.

VERTIKÁLIS EGYENSÚLYTALANSÁG, ILLETVE A KÖZPONTI KÖLTSÉGVETÉSI VÁLSÁGKEZELÉS TOVÁBBHÁRÍTÁSA - A túlzott eladósodás egyik oka az úgynevezett vertikális egyensúlytalanság, ${ }^{8}$ ha az helyi hitelfelvételi jogosultsággal társul. Azok a regionális és helyi önkormányzatok, amelyek nem rendelkeznek elegendö saját adóbevétellel, hajlamosak a túlzott eladósodást is vállalni közszolgáltatásaik fenntartásáért.

Kellő bevételi autonómia hiányában könnyen konfliktus alakulhat ki a központi kormányzat és a helyi önkormányzatok között: például a központi válságkezelés az önkormányzatok költségvetését is nyomás alá helyezi (csökkenti a transzfereket, vagy elvonja a helyi adók egy részét). Ezáltal csökkennek az önkormányzatok bevételei, miközben feladataik változatlanok maradnak. Emiatt nagy és tartós önkormányzati deficitek alakulhatnak ki, amelyeket hitelekből finanszíroznak, fenntarthatatlan pénzügyi helyzetet teremtve ezzel. Több ilyen esetre is találunk külföldi példát:

- Olaszországban az 1972-1973-as adóreform jelentősen megnyirbálta a helyi önkormányzatok saját bevételeik feletti autonómiáját. 1977-1978-ra sok önkormányzat költségvetési válságba került (Hagen és szerzőtársai [2000]).

- Spanyolország központi költségvetésében számottevő hiány alakult ki a 2008-as válságot követően. Az államadósság nehezen kezelhetővé vált, jelentős költségvetési kiigazítást követelve. A regionális és helyi szintek jóval kevesebb támogatáshoz jutottak a központi költségvetésből, amit nem követett a kiadások drasztikus visszavágása. Emiatt három év alatt számos régió csődközelbe került (Jenkner-Lu [2014]).

ÁltALÁNOS MAKROGAZDASÁGI, ILLETVE SZUVERÉN KÖLTSÉGVETÉSI VÁLSÁG • Sok esetben a helyi önkormányzatok nem tudják függetleníteni magukat az általános makrogazdasági válságtól, illetve a központi kormányzat költségvetési válságától, így egyszerre alakul ki országos és regionális/helyi költségvetési válság. (Ezt láthattuk Svédországban, Spanyolországban és néhány latin-amerikai országban.) Roszszabb esetben az ország csődjével együtt a regionális és helyi kormányzatok egy része is fizetésképtelenné válik (Cordes és szerzőtársai [2015]). ${ }^{9}$

\footnotetext{
${ }^{8}$ A központi kormányzat adóbevételei általában meghaladják kiadásait, míg az önkormányzatoknál fordított a helyzet. Az önkormányzatoknak juttatott központi támogatás oldja fel az államháztartási alrendszerek közötti egyensúlytalanságot.

${ }^{9}$ Az idézett forrás latin-amerikai (argentin és brazil) példákat említ, de megjegyezzük, hogy az 1998-as orosz pénzügyi összeomlás is ilyen helyzetet teremtett.
} 


\section{A költségvetési válsághoz vezetö lokális tényezök}

A HELYi gAZdASÁG STRUKTURÁlis VÁLSÁGA • Egyes régiók gazdasága kevéssé diverzifikált (például egyoldalúan nehézipar, autógyártás, mezőgazdaság stb. központú), ezért nem eléggé ellenálló a sokkokkal szemben. Így a domináns szektort érintő, külső eredetű gazdasági sokk nagymértékű visszaesést okozhat, visszavetve az önkormányzati bevételeket is. A kiadások jelentős része alapvető közszolgáltatásokat finanszíroz, amelyeket az önkormányzat igyekszik fenntartani. Ha nem érkezik központi segítség, tartós pénzügyi egyensúlytalanság alakulhat ki az adott regionális vagy helyi önkormányzatnál. Ilyen válságra jó példa a német Saar-vidék és Bréma válsága az 1980-as évek végén, amelyet a nehézipar hanyatlása váltott ki (Hagen és szerzőtársai [2000]).

Hely POLITIKa • Az önkormányzatok eladósodását bizonyos politikai elemek is befolyásolhatják. A szakirodalom szerint a hatalmon lévő párt ideológiája és a helyi önkormányzati vezetők hatalmának szilárdsága befolyásolhatja az önkormányzati eladósodás szintjét. Az önkormányzati vezetők hatalmát szilárdnak tekinthetjük, ha a helyi kormányzatban valamelyik párt abszolút többséget szerez. Ilyen helyzetben ugyanis a vezetők kevésbé érzik fenyegetve a hatalmukat (kisebb a politikai verseny), így kevésbé használják politikai célból a költségvetési túlköltekezés rövid távú eszközét. Ami az ideológiai kötődést illeti: a jobboldali pártok által vezetett önkormányzatok költségvetésének általában kisebb a hiánya, és mérsékeltebb az adósságállományuk. Ez nem általános érvényü szabály, de egyes országokban találtak ilyen összefüggéseket. Például Vicente Lama és szerzőtársai [2017] spanyol önkormányzati adatokon szignifikáns kapcsolatot mutatott ki a hatalmon lévő párt ideológiája és az eladósodás mértéke között. Más országokban viszont nem sikerült feltárni ilyen kapcsolatot. Például Seitz [2000] a német tartományi és helyi kormányzatok esetében nem talált ilyet.

EgYES ÖNKORMÁNYZATI INTÉZMÉNYEK NAGYARÁNYÚ ELADÓSODÁSA • Az önkormányzatok a jelentős finanszírozási igénnyel járó fejlesztési, illetve szolgáltatási tevékenységeiket (például önkormányzati bérlakások üzemeltetése, közművek fenntartása) gyakran külön intézménybe szervezve végzik. Ezek jelentős adósságállománya - összekapcsolódva a már említett negatív pénzpiaci folyamatokkal (az általános adósságszolgálati költségek emelkedése) és a gyenge transzparenciával (sokáig rejtve marad ezen adósságok mérete) - fenntarthatatlan pénzügyi helyzetet teremthet. Példaként a svéd önkormányzati lakásépítő cégek fenntarthatatlan adósságállományát említhetjük (Hagen és szerzőtársai [2000]).

\section{Nemzetközi válságkezelési eszközök és tapasztalatok}

Az önkormányzati válságkezelésröl két nagy hullámban szerezhettünk tapasztalatokat: az 1970-es évektől az 1990-es évek végéig tartó, illetve a 2008-as válságot követő időszakban. Az állampolgárokat közvetlenül érintő közszolgáltatásokat (egészségügy, 
oktatás, lakhatás) mindenütt garantálni kell. Emiatt az országok még a kisebb önkormányzatok csődjét sem engedhetik meg. Hagen és szerzőtársai [2000] részletesen bemutatta, hogy például Németországban a két legkisebb tartomány, míg Olaszországban is inkább a kisebb régiók és önkormányzatok kaptak központi segítséget az adósságuk rendezéséhez. Tehát itt - a bankrendszertől eltérően - nem a méret és az abból eredő rendszerkockázat, hanem a közszolgáltatások univerzalitásának követelménye okozza, hogy a központi kormányzatok kimentik a nehéz pénzügyi helyzetben lévő önkormányzatokat. Hagen és szerzötársai [2000] megfogalmazása szerint itt egy „túl érzékeny ahhoz, hogy csődbe mehessen" problémával állunk szemben.

Megjegyezzük, hogy Beck és szerzőtársai [2016] szerint bizonyos esetekben a „túl nagy ahhoz, hogy meg lehessen menteni" (too big to be rescued) jelenség is fennállhat. A szerzők azt találták, hogy a jelentősebb gazdasági erejü régiók, illetve tartományok nagyobb kockázati felárat fizetnek a tőkepiacon. Ezt azzal magyarázták, hogy a piac megítélése szerint a központi kormány szanálási kapacitása korlátozott, és nem lesz képes teljesen kimenteni az adott régiót vagy tartományt. Ezzel az érveléssel két okból sem értünk egyet: 1 . az eddigi regionális és helyi költségvetési válságok tapasztalatai egyáltalán nem támasztják alá (nem volt olyan eset, hogy a nagyobb tartományt kevésbé segítették volna meg); 2. a nagyobb tartományok csődjét - politikai és gazdasági okokból - még kevésbé engedheti meg magának egy központi kormány. A Beck és szerzötársai [2016] által talált összefüggés inkább azt a kockázatot tükrözheti, hogy a nagy régiókban és tartományokban a válságkezelés időben elhúzódhat, illetve sikeressége bizonytalanabb. De nem azt jelenti, hogy ezek nem kapnak központi segítséget a túl nagy méretük miatt!

A pénzügyi segítségnyújtással kapcsolatban azt is gyakran feltételezik, hogy abban megjelenik a központi döntéshozók politikai preferenciája is: azonos politikai táborba tartozó helyi önkormányzatoknak könnyebben/szívesebben nyújtanak segítséget. Az empirikus adatok ezt a hipotézist több (svéd és német) esetben alá is támasztották (Hagen és szerzőtársai [2000]).

Ami a válságkezelés eszközrendszerét illeti, néhány országban már a válságot megelőzően rendelkezésre álltak előre meghatározott válságkezelési keretek, jellemzően azonban a központi kormányzatok a válság hatására ad hoc módon nyújtanak valamilyen központi pénzügyi segítséget.

\section{Elöre meghatározott válságkezelési keretek}

Csak kevés országban (például az Egyesült Államokban, Spanyolországban vagy Svájcban) müködik olyan rendszer, amely hitelesen garantálja, hogy a helyi önkormányzatok csődje esetén a központi kormányzatnak egyáltalán nem jelentkezik pénzügyi kötelezettsége. Ezekben az országokban jogszabályok rögzítik a regionális és helyi válságok kezelésére alkalmazható eszközöket. Ugyanakkor a gyakorlat azt mutatja, hogy még ezekben az országokban is adódhat olyan helyzet, hogy a központi kormányzat mégis beavatkozik, és pénzügyileg konszolidálja az önkormányzati szektort. (Ez történt Spanyolországban 2012-ben.) 
Az esetek többségében a helyi önkormányzatok úgynevezett puha költségvetési korláttal szembesülnek, azaz többé-kevésbé számíthatnak központi segítségnyújtásra. Ezért az önkormányzati szektor pénzügyi helyzete a központi kormányzat hitelbesorolását is befolyásolja. A puha költségvetési korlát gyakori jellemzője, hogy a válságkezelési eszközrendszer nincs elöre kidolgozva, hanem esetfüggő.

\section{Ad hoc központi válságkezelési intézkedések}

A költségvetési válságba került regionális vagy helyi önkormányzatok pénzügyi megsegítésére többféle gyakorlatot találunk. Hagen és szerzőtársai [2000] ezen intézkedéseket egyrészt a pénzügyi segítségnyújtás módja, másrészt a hozzájuk kapcsolódó feltételek szerint csoportosítja.

A szerzők a pénzügyi segítségnyújtás módja szerint a következő eszközöket különböztetik meg:

- a regionális és helyi hitelekhez kapcsolódó központi garancia- vagy kezességvállalás (Olaszország);

- a központi kormányzat közvetlen vagy közvetett (állami bankok közbeiktatásával történő) hitelnyújtása a regionális és helyi kormányzatnak;

- rendkívüli (akár több éven át folyósított) támogatás juttatása a válságban lévő regionális vagy helyi önkormányzatnak (a pénzügyi segítségnyújtásnak ez a leggyakoribb módja).

A központi pénzügyi segítségnyújtás általában a következő feltételek egyikével vagy ezek kombinációjával járt együtt:

- a költségvetési fegyelemre (a hiány mértékére, a kiadások csökkentésére) vonatkozó elöírások;

- a költségvetési könyvelés rendszerére, transzparenciájára, illetve az adatszolgáltatásra vonatkozó követelmények erősítése;

- egyes esetekben a bajba jutott regionális vagy helyi önkormányzatok adminisztratív felügyelete (például a központi kormányzat a válságkezelés idejére válságmenedzsert nevez ki a bajba jutott regionális vagy helyi kormányzat fölé).

A válságokat követően - a rossz tapasztalatok következtében - több esetben az önkormányzati autonómiát is szűkítették, ami elsősorban az új hitelfelvételre vonatkozó adminisztratív kontrollok bevezetését jelentette (Brazília, Argentína esetében az 1990-es években vagy Oroszországban 2000-ben).

\section{Önkormányzati eladósodás Magyarországon}

Magyarországon az államszocialista rendszer demokratikus átalakulása jelentős változást hozott az önkormányzati müködés terén is. Nagymértékü decentralizáció zajlott, az önkormányzatok széles gazdálkodási és szervezetalakítási önállóságot kaptak, 
s emellett lényegesen megnőtt a központi kormányzattól „letelepített” feladatok köre is. A feladatok ellátásához azonban az önkormányzatok nem mindig kaptak elegendő központi forrást, aminek következtében a helyi államháztartási alrendszerben az ezredfordulótól tartós müködési hiány keletkezett. Általánossá vált, hogy az önkormányzatok a működési kiadásaik finanszírozására fejlesztési forrásokat, beruházási hiteleket használtak fel (Lentner [2014]).

Tehát a szakirodalomból ismert vertikális egyensúlytalanság jellemezte a magyar önkormányzati alrendszert, ami önmagában is eladósodáshoz vezetett. Ezt a vertikális egyensúlytalanságot 2005-től felerősítette a központi kormányzat költségvetési szigorítása: a közfeladatok központi költségvetési támogatása általában is, az önkormányzati szférában is csökkent. 1994-től 2001-ig a teljes magyar önkormányzati szektor GFS-módszertan szerint számított költségvetési egyenlege csak a privatizációs bevételeknek köszönhetően maradt pozitív. (Ezek nélkül az önkormányzatok már ebben az időszakban is deficitesek lettek volna.) 2002-től gyakorlatilag állandósult a hiányuk, amelynek mértéke 2009-ig átlagosan a GDP 0,35 százaléka volt (Vigvári [2009]), ez pedig folyamatos eladósodáshoz vezetett. ${ }^{10}$

Az önkormányzati adósságrendezési törvény fizetésképtelenség esetére kizárta az állami kisegítés lehetőségét. A hátrányos helyzetben lévő önkormányzatok azonban, ha a saját hibájukon kívüli ok miatt kerültek bajba, állami többlettámogatást kaphattak (Vigvári [2010]). Így a magyar rendszerben végső soron fennmaradtak a puha költségvetési korlát elemei.

Az eladósodást tovább erősítette az, hogy 2004-től az önkormányzatok elött jelentős mértékủ európai uniós fejlesztési támogatások nyíltak meg a feladataik ellátásához szükséges infrastrukturális háttér biztosítására. A megszerzett támogatások felhasználásához az önkormányzatoknak szükséges önrészt saját maguknak kellett elöteremteniük; központi forrást ehhez nem kaptak. A folyó költségvetésükből általában ezt nem tudták biztosítani, ezért gyakran adósságból finanszírozták az önrészt.

Sok esetben a beruházási hitelek visszafizetésének forrása nem volt látható a hitelfelvételkor. Az uniós támogatásokat, valamint a felvett hiteleket többnyire infrastrukturális, azaz nem termelő (vagy müködési kiadást csökkentő) beruházásokra fordították. A magyar önkormányzatok gyakran nem számoltak a beruházásból létrejövő vagyontárgyak amortizációjával, fenntartási kötelezettségeivel (ÁSZ [2012]). Mivel e beruházások gyakran nem generálnak közvetlenül bevételt (vagy e bevétel nem volt elegendő a fenntartáshoz), a hitelek törlesztését az önkormányzatoknak jelentős részben más forrásokból kell(ett) biztosítaniuk.

A központi ellenőrzés és transzparencia gyengesége tovább súlyosbította a helyzetet. Az elégtelen ellenőrzést részben jogszabályi kötöttségek is okozták: az Állami Számvevőszék például 2011-ig nem volt jogosult az önkormányzati tulajdonban lévő vállalatok ellenőrzésére.

${ }^{10} \mathrm{Az}$ önkormányzatok pénzügyi stabilitása összetett és többdimenziós kérdéskör (lásd például Bolívar és szerzőtársai [2016] összefoglalását). Ugyanakkor az önkormányzati deficit és pénzügyi mérleg hosszabb távú elemzése alapján már meglehetősen pontos képet kaphatunk a szektor költségvetési stabilitásáról. 
Ha egy önkormányzati tulajdonú vállalat eladósodik, és erre a hitelre az önkormányzat garanciát nyújt, akkor ez az önkormányzat számára egy feltételes kötelezettségvállalás, amely az önkormányzat pénzügyi beszámolójában nem jelenik meg, viszont a vállalat fizetési problémája esetén tényleges kötelezettséggé válhat. Ez a fajta kötelezettségvállalás jelentősnek bizonyult a főváros és egyes megyei önkormányzatok esetében (Hegedüs-Tönkő [2006]). Így az önkormányzatok tulajdonában álló vállalkozások - a korábban említett spanyolországi helyzethez hasonlóan - alkalmasak voltak a költségvetési hiány költségvetésen kívülre helyezésére.

Nagyobb beruházásigényü fejlesztések - amelyeket gyakran önkormányzati tulajdonú gazdasági társaságok valósítottak meg - más országokban (például a svéd önkormányzati rendszerben) is okoztak költségvetési problémát. A magyar tapasztalatok azt mutatják, hogy a jelentős központi (uniós és nemzeti) fejlesztési támogatások, ha nem egy átgondolt fejlesztéspolitika keretében használják föl őket, hosszú távon a várttal ellentétes hatást válthatnak ki, gyengítve a helyi önkormányzatok költségvetési stabilitását.

Az eladósodásnak ugyanakkor volt egy másik sajátossága: a válság kirobbanását közvetlenül megelőző két évben (2006-2008-ban) az önkormányzatok a hitelfelvétellel és kötvénykibocsátással bevont - összesen mintegy 460 milliárd forintos - hosszú lejáratú forrásaik körülbelül egynegyedét a meglévő tartozásaik csökkentésére fordították, háromnegyed részüket viszont bankbetétbe, illetve kisebb részben értékpapírokba fektették. A szakértők többféleképpen magyarázták ezt a jelenséget (Vigvári [2009], Homolya-Szigel [2008]).

- Az alacsony kamatozású (háromnegyed részben svájci frankban denominált) devizaforrást magasabb kamatozású forintbetétek formájában helyezték el, 2007-ben és 2008-ban a szektor nettó kamatbevétele jelentősen növekedett. Az ebből a spekulációból származó kamatelőny tovább növelte a helyi döntéshozók pénzbőséggel kapcsolatos illúzióját. A spekulatív jelző helytálló, az önkormányzatok a kamatnyereségért cserébe vállalták a többlet- (árfolyam-) kockázatot, azonban ezzel a kockázattal nem mindig voltak tisztában.

- A jövőbeli finanszírozási helyzetüket övező bizonytalanság (többek között az önkormányzati hitelfelvétel törvényi korlátjának a szigorításától való félelem miatt) elörehozták a hitelfelvételüket. Ennek egyik közvetlen oka az volt, hogy a 2007-ben kezdődő uniós programozási időszakban az Európai Unió által társfinanszírozott támogatások igénybevételéhez szükséges öneröt elöre kívánták biztosítani.

- A hitelfelvételek ilyen mértékű terjedéséhez az erős banki verseny, illetve a bőséges hitelkínálat is hozzájárult.

Az 1. táblázatból látszik, hogy 2002-től lassan megindult a szektor eladósodása, amely 2007-től jelentősen felgyorsult. Az eladósodásnak volt egy technikai sajátossága is. A gyors adósságfelfutás döntő része kötvénykibocsátás formájában történt. Ez azonban egy szabályozási arbitrázsnak volt köszönhető: a hitelfelvétellel szemben a kötvények kibocsátásakor nem volt kötelező közbeszerzési eljárást lefolytatni. A szabály mögött valószínüleg az a feltételezés állt, hogy a tőkepiaci kötvénykibocsátást nem lehet versenyeztetni, a legjobb végrehajtás elve (best execution) itt könnyen teljesülhet. 


\section{1. táblázat}

A magyar önkormányzatok pénzügyi mérlegének fö összetevői, 2001-2014 (milliárd forint)

\begin{tabular}{|c|c|c|c|c|c|}
\hline & \multicolumn{5}{|c|}{ Eszközök } \\
\hline & $\begin{array}{c}\text { készpénz és } \\
\text { betétek }\end{array}$ & $\begin{array}{l}\text { hitelviszonyt } \\
\text { megtestesítő } \\
\text { értékpapírok }\end{array}$ & hitelek & $\begin{array}{l}\text { részvények és } \\
\text { részesedések }\end{array}$ & egyéb eszköz \\
\hline 2001 & 199 & 130 & 37 & 695 & 25 \\
\hline 2002 & 228 & 77 & 47 & 698 & 20 \\
\hline 2003 & 223 & 55 & 47 & 692 & 23 \\
\hline 2004 & 254 & 71 & 45 & 695 & 26 \\
\hline 2005 & 254 & 53 & 43 & 712 & 28 \\
\hline 2006 & 257 & 42 & 42 & 711 & 35 \\
\hline 2007 & 397 & 51 & 41 & 744 & 32 \\
\hline 2008 & 564 & 90 & 41 & 736 & 31 \\
\hline 2009 & 561 & 26 & 41 & 734 & 32 \\
\hline 2010 & 400 & 12 & 41 & 808 & 50 \\
\hline 2011 & 418 & 16 & 35 & 787 & 51 \\
\hline 2012 & 422 & 14 & 49 & 859 & 35 \\
\hline 2013 & 503 & 17 & 49 & 859 & 57 \\
\hline \multirow[t]{3}{*}{2014} & 562 & 15 & 38 & 880 & 51 \\
\hline & \multicolumn{5}{|c|}{ Források } \\
\hline & $\begin{array}{l}\text { hitelviszonyt } \\
\text { megtestesítő } \\
\text { értékpapírok }\end{array}$ & hitelek & kere & $\begin{array}{l}\text { delmi hitelek } \\
\text { lőlegek }\end{array}$ & gyéb tartozások \\
\hline 2001 & 23 & 143 & & 39 & 101 \\
\hline 2002 & 24 & 237 & & 50 & 108 \\
\hline 2003 & 6 & 274 & & 57 & 112 \\
\hline 2004 & 6 & 334 & & 66 & 156 \\
\hline 2005 & 4 & 413 & & 93 & 184 \\
\hline 2006 & 28 & 541 & & 117 & 197 \\
\hline 2007 & 213 & 571 & & 105 & 147 \\
\hline 2008 & 452 & 577 & & 93 & 95 \\
\hline 2009 & 484 & 604 & & 124 & 103 \\
\hline 2010 & 609 & 649 & & 137 & 113 \\
\hline 2011 & 554 & 660 & & 144 & 124 \\
\hline 2012 & 484 & 592 & & 105 & 97 \\
\hline 2013 & 165 & 301 & & 117 & 57 \\
\hline 2014 & 7 & 39 & & 130 & 50 \\
\hline
\end{tabular}

Forrás: MNB pénzügyi számlák. 
A tapasztalatok azonban azt mutatták, hogy a kötvényeknek nem alakult ki másodlagos piaca, ezek a lejegyző bank könyveiben maradtak, így csak technikai értelemben beszélhetünk tőkepiaci finanszírozásról. Ez utóbbi az adósságkonszolidáció szempontjából szerencsésnek bizonyult, mert így az adósságátvállalásról sokkal könnyebb volt megegyezni, mint ha tőkepiacon forgó, „valódi” kötvények lettek volna.

Az adósság deviza-összetétele önmagában rendszerkockázatot hordozott. A hitelek jelentős része devizában, ráadásul döntően svájci frankban denominált volt, míg az önkormányzatok nem rendelkeztek devizabevételekkel.

A svájci frank használata - a rövid távú kamatelőny ellenére - sokkal kockázatosabbnak bizonyult az euróalapú hitelfelvételhez képest:

- Magyarország árfolyam-politikája az euróhoz kötődött, az euró-svájci frank keresztárfolyamra semmilyen ráhatással nem volt;

- a svájci frank menekülődeviza, tehát a korábbi évtizedek tapasztalatai alapján egy nemzetközi gazdasági válság esetén erősödésére lehet számítani;

- a spekulatív célú alacsony kamatozású hitelek felvételével (az úgynevezett carry trade-del) kapcsolatos irodalomban egyértelmüen megjelenik, hogy a magas kamatozású devizák gyakran hosszú felértékelödésen mennek keresztül, amelyet hirtelen nagy gyengülések szakítanak meg. Tehát hosszabb távon nagy valószínűséggel akkora árfolyamveszteséget lehet egy ilyen pozíción elszenvedni, amely az összes addig keletkezett kamatnyereséget felemészti.

Az euróban történő hitelnyújtás is megjelent a hitelintézetek kínálatában, de a svájci frankban denominált termékek játszottak főszerepet, mert ezek nagyobb kamatelőnyt tudtak biztosítani.

A szakirodalom a regionális és helyi önkormányzatok esetében a fedezetlen devizahitelfelvételt mint jelentős kockázatot nem emeli ki. A magyar önkormányzati szektor költségvetési válságában viszont ennek a tényezőnek egyenesen kulcsszerepe volt. A válság kirobbanását követően a forint jelentősen gyengült az euróhoz, illetve a svájci frankhoz képest, nagymértékben rontva az önkormányzatok mérlegpozícióját.

A magyar önkormányzati szektor nettó pénzügyi vagyonának változását bemutató 1. ábrán jól látható a fenti tényezők hatása. A 2000-es évek elejétől a nettó pénzügyi vagyon (eszközök mínusz kötelezettségek) elöször csak kismértékben, majd egyre gyorsuló ütemben csökkent, és 2010-re már negatívvá vált. A változást döntően a kötelezettségek megugrása idézte elö, ami nagyobb részben devizahitel felvételéhez kapcsolódott. Ennek következtében a szektor mérleg szerinti devizapozíciója jelentősen megugrott.

Az elmondottak miatt a 2008-as gazdasági válságot megelözően jelentős költségvetési kockázatok alakultak ki a magyar önkormányzati körben. Az önkormányzati rendszer pénzügyi instabilitása hatással volt az egész államháztartásra. A válság következtében romlott az önkormányzatok likviditása; egyszerre jelentkezett felhalmozási és működési forráshiány. Sok önkormányzatnak nem volt fedezete az uniós támogatással létrejövő projektek előfinanszírozására. A folyamatban lévő beruházások miatt a szektor 2010 végén a saját bevételein felül további 217 milliárd forint külső forrást igényelt. Az önkormányzatok kötelezettségei - elsősorban az árfolyamváltozások 


\section{1. ábra}

A magyar önkormányzati szektor konszolidált pénzügyi eszközei; hitel, kötvény és szállítói tartozásai, valamint a mérleg szerinti nyitott devizapozíciója, 1989-2017 (milliárd forint)

\section{Milliárd forint}

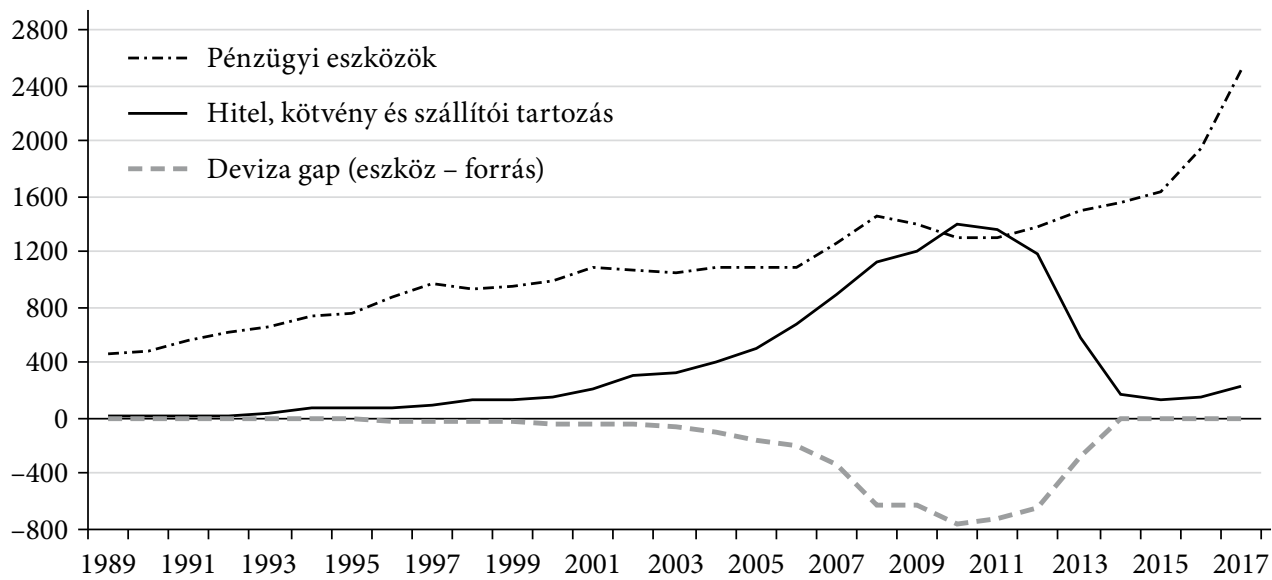

Megjegyzés: a forrásoldalon az egyéb kötelezettségeket nem tüntettük fel, mert egy részük a támogatások elszámolására szolgál.

Forrás: MNB, saját szerkesztés.

miatti átértékelődés és a növekvő szállítói állományok miatt - növekedtek. A duzzadó adósságállomány azért vált jelentős kockázattá, mert az önkormányzatok nem gondoskodtak a visszafizetéshez szükséges tartalékokról, illetve a törzsvagyonukhoz tartozó vagyonelemeket is felajánlottak a hitelek fedezetére (ÁSZ [2012]). Az előbbiek miatt az adósságrendezési eljárások tömegére lehetett számítani, ami szélesebb körben is veszélyeztette volna a közfeladatok ellátását. A magyar állam ebben az időszakban egyébként is számottevő csődkockázatát az önkormányzati szektorból esetlegesen tömegesen érkező negatív hírek tovább növelhették volna.

Egyes szerzők amellett érvelnek, hogy akár adósságkonszolidáció nélkül, a meglévő eszközrendszerrel (adósságrendezési eljárások, saját bevételek növelése) is stabilizálni lehetett volna a szektor adósságállományát (Gyirán [2016]), de a forint sokkszerü gyengülése (elsősorban a svájci frankkal szemben) biztosan komoly problémát okozott volna a szektor sok szereplöjénél. Ezt tetézte volna még a lejáró hitelek és kötvények megemelkedett megújítási kockázata. A magyar bankszektor hitelkínálata ugyanis jelentősen csökkent a válság hatására, $s$ a hitelezési feltételek csak 2015-től kezdve enyhültek. Így a lejáró hitelek megújítása jelentős nehézséget okozott volna a szektorban.

\section{A magyar adósságkonszolidáció tapasztalatai}

A világ országai általában a következö eszközöket használták a költségvetési válságba került önkormányzatok kimentésére: központi garancia az önkormányzati hitelekre, közvetlen vagy közvetett hitelnyújtás, valamint rendkívüli pénzügyi támogatás. 
A magyar kormány ezektől részben eltérö, újszerü eszközrendszert vezetett be a válságkezelés keretében (2. táblázat):

- a kötelezö feladatok kormányzati átvállalásával 2011 végén rendeződött a megyei jogú önkormányzatok adósságállománya,

- a kormányzat 2012 végén egyszeri, vissza nem térítendő költségvetési támogatást nyújtott az ötezernél kisebb lélekszámú településeknek az adósságuk rendezésére,

- 2013-ban az ötezer fő feletti települések esetében történt részbeni adósságátvállalás,

- 2014-ben pedig minden önkormányzat és önkormányzati társulás fennmaradt adósságát konszolidálták.

\section{2. táblázat}

A konszolidált összegek és az érintett önkormányzatok

\begin{tabular}{llcc}
\hline Év & Konszolidációban részt vettek köre & $\begin{array}{c}\text { Az érintett } \\
\text { önkormányzatok száma }\end{array}$ & $\begin{array}{c}\text { Konszolidált összeg } \\
\text { (milliárd forint) }\end{array}$ \\
\hline 2011 & megyei önkormányzatok és a föváros & 20 & 198 \\
2012 & $\begin{array}{l}5000 \text { fö alatti önkormányzatok } \\
\text { és többcélú kistérségi társulások }\end{array}$ & 1740 & 85 \\
2013 & $\begin{array}{l}5000 \text { fö feletti települések részbeni } \\
(40-70 \%) \text { konszolidációja }\end{array}$ & 279 & 614 \\
2014 & $\begin{array}{l}\text { minden fennmaradt önkormányzat } \\
\text { és társulási adósság konszolidációja }\end{array}$ & 516 & 472 \\
& Összesen & 2078 & 1369 \\
\hline
\end{tabular}

Forrás: saját összeállítás a költségvetési törvények alapján.

Az Európai Unió 2013 közepén megszüntette a Magyarországgal szemben 2004 óta folytatott túlzotthiány-eljárást. Látható, hogy a központi költségvetés adósságátvállalásának döntő része ezután következett be. Megjegyezzük, hogy az időzítés más szempontból is megfelelő volt. A szektor nyitott svájcifrank-pozíciója még a svájci frank 2015. januári nagymértékü további erősödése előtt megszünt. ${ }^{11}$

A konszolidáció két fontos elemét kell kiemelnünk.

1. A megyei önkormányzatok és a főváros adósságállományának átvállalása valójában nem adósságkonszolidáció volt, hanem feladatoknak a meglévő kötelezettségekkel együtt történő átvállalása. A megyei önkormányzatoktól teljes körü és általános jogutódlással az államhoz került az általuk fenntartott intézmények (elsősorban a kórházak, rendelőintézetek, iskolák) fenntartói joga. Mivel a megyei önkormányzatoknak csak ezen intézményeik miatt voltak adósságaik, ők gyakorlatilag minden kötelezettségüktöl mentesültek. A szállítói tartozásokat a hitelezők az állammal szemben érvényesítették, a devizaalapú kötvények az Államadósság Kezelő Központhoz, az egyéb forintkötelezettségek pedig a Magyar Államkincstárhoz kerültek.

${ }^{11}$ 2015. január 15-én a svájci nemzeti bank feladta a svájci frank/euró árfolyamküszöböt, amit a svájci frank nagyon nagy mértékủ és hirtelen erősödése követett, jelentős turbulenciát okozva a pénzés tökepiacokon. 
2. Eltérő technikát alkalmazott a kormány az ötezer fő alatti és e feletti önkormányzatok esetében. A kisebbeknek az állam vissza nem térítendő költségvetési forrásokat adott át egyszeri törlesztési célú támogatás címén. Ez a módszer összhangban volt az addigi nemzetközi gyakorlattal. Az érintett önkormányzatok képviselö-testületeinek kellett dönteniük arról, hogy kérik-e az államtól a tartozás átvállalását. Valamennyi érintett önkormányzat kérte az állami tartozásátvállalást. A konszolidáció részét képező költségek körét a kormány és a Bankszövetség között létrejött különmegállapodás rendezte. Az adott fordulónapon fennálló tartozások összegét a Magyar Államkincstár átutalta az önkormányzatoknak, amelyek azt adósságtörlesztésre fordították.

Az ötezer fő feletti lakosságszámú települések önkormányzatának jelentősebb adósságállományát más módszerrel kezelte az állam: itt tényleges adósságátvállalás történt. ${ }^{12}$ A normál tartozásátvállalás önmagában csak a jogi kötelem kötelezetti pozíciójában okoz alanyváltozást: bár a tartozásátvállaló a kötelezett helyébe lép, ez nem jelenti a teljes szerződéses alanyi pozíció jogutódlását. Ezért jogtechnikai szempontból szükségessé vált egy háromoldalú (a hitelező bank, az önkormányzat, valamint az állam részvételével) szerződéssel történő kiegészítés megkötésére a teljes szerződéses pozíció jogutódlásának érdekében. Ennek keretében a teljes szerződéses alanyi pozícióban bekövetkező valamennyi jogra és kötelezettségre kiterjedő engedményezéssel és tartozásátvállalással kapcsolatban megállapodtak. Ezért az adósságkonszolidációt megelözte a Bankszövetséggel történő egyeztetés, illetve az önkormányzatok részvételével történő társadalmi egyeztetés. A konszolidáció során átvállalt teljes adósságállomány a GDP 4,2 százalékát tette ki.

A nemzetközi tapasztalatok is azt mutatták, hogy a központi pénzügyi segítségnyújtás általában együtt jár költségvetési fegyelmező eszközök alkalmazásával és költségvetésre, valamint a transzparenciára, illetve adatszolgáltatásra vonatkozó követelmények erösítésével. Bizonyos estekben pedig az önkormányzati autonómiát is szükítik. Ezek az elemek mind megjelentek a magyar válságkezelésben is:

- a transzparencia növelésére a központi források esetében áttértek a feladatalapú finanszírozásra;

- a helyi gazdálkodás fokozottabb ellenőrzésének céljából kibővítették az Állami Számvevőszék jogkörét, amely immár az önkormányzati gazdasági társaságokra is kiterjed;

- az önkormányzatiadósság-keletkezés engedélyezési rendszerét jelentősen megszigorították az ismételt túlzott eladósodás elkerülésére, ezenkívül müködési hiány tervezését is megtiltották; ezek eredményeként 2014-töl - a föváros nélkül - igen alacsony szintü (mindössze évi 5-20 milliárd forint) új adósságfelvétel történt;

- az adósságkonszolidációval párhuzamosan az önkormányzati feladatköröket is jelentősen leszűkítették, a feladatok nagy részét központosították. Ennek a centralizációnak a részeként jelentős köznevelési, oktatási, egészségügyi és államigazgatási

\footnotetext{
${ }^{12}$ A kis összegű adósságok esetében itt is elötörlesztés történt közvetlenül a bankok számára állami támogatás formájában kapott forrásból.
} 
feladatok kerültek át a központi kormányzathoz. Ez költségvetési szempontból csökkenti a vertikális egyensúlytalanság lehetséges mértékét. Ugyanakkor több érv szól amellett, hogy a túlzott koncentráció nem feltétlenül a legkedvezőbb megoldás például az egészségügyben, ahol a központi kormányzat látja el a szabályozó, a tulajdonosi és az irányító, valamint a finanszírozó funkciókat egyaránt (Mihályi [2012]). Megjegyezzük, hogy közben az ellátás intézményi struktúrája (sok kis kórház) változatlanul fennmaradt.

Az önkormányzatok állami kimentése a puha költségvetési korlát megnyilvánulásának is tekinthető. Az ebből fakadó erkölcsi kockázatot a magyar kormány úgy kívánta tompítani, hogy a konszolidációban részt nem vevő önkormányzatok számára 20142016-ban 46,8 milliárd forintos fejlesztési támogatást nyújtott.

A hazai szakirodalomban további kutatási kérdésként adódik, hogy az ismertetett konszolidáció egy egyszeri kimentés volt-e, amelynek ára az önkormányzatok számára egy „erőteljes centralizáció”, vagy az új rendszerben terjedni fog a puha költségvetési korláttal jellemzett bánásmód, és gyakorivá válik egyes önkormányzatok eseti „kimentése”. A vita eldöntését segítheti, ha a későbbiekben egyedi mikroadatokon is megvizsgáljuk: mennyire fenntartható az önkormányzati szektor müködése az új gazdálkodási rendszerben.

\section{Összefoglalás és következtetés}

Tanulmányunkban némileg kibővítve áttekintettük az önkormányzati eladósodás kialakulásának és kezelésének nemzetközi gyakorlatáról szóló elemzést (Hagen és szerzőtársai [2000]), valamint Cordes és szerzötársai [2015] kutatásait. Ezen eredményekkel vetettük egybe a magyar önkormányzati szektor eladósodásának és konszolidációjának a tapasztalatait. Bemutattuk azokat a tényezőket is, amelyek atipikussá teszik a magyar önkormányzati válságot és válságkezelési technikát.

A tanulmányunkban kitértünk a kemény és puha költségvetési korlát problematikájára. A szakirodalomból jól ismert, hogy a puha költségvetési korlát kevésbé felelős önkormányzati gazdálkodáshoz vezethet. További jellemző, hogy a válságkezelés eszközrendszere általában nincs elöre meghatározva, eseti. Ugyanakkor a kemény költségvetési korlát rendszerének is megvannak a maga negatívumai, hiszen nemcsak a felelőtlen gazdálkodás okozhat gondot, hanem nem várt negatív külső tényezők is fenntarthatatlanná tehetik az önkormányzatok adósságát.

A túlzott eladósodás okozta költségvetési válságok ellehetetleníthetik az állam müködését, és nagymértékben ronthatják a lakosság életminőségét. A helyhatóságok jelentős mértékủ közszolgáltatási tevékenységet végeznek, így esetleges ellehetetlenülésük jelentős politikai és jogi (közszolgáltatásokhoz való egyenlö hozzáférés joga) kockázatokat hordoz. Így a pénzintézeteknél jelen lévő „túl nagy ahhoz, hogy csődbe mehessen” problémától eltérő jelenséget tapasztalhatunk, melyet „túl érzékeny ahhoz, hogy csődbe mehessen” (Hagen és szerzötársai [2000]) vagy „túl állami ahhoz, hogy csődbe mehessen" problémaként írhatunk le. 
Magyarországon az államszocialista rendszer demokratikus átalakulása jelentős változást hozott az önkormányzati müködés terén is. Nagymértékủ decentralizáció történt, amely együtt járt a szakirodalomból ismert vertikális egyensúlytalansággal, amely önmagában is eladósodáshoz vezetett. Ezt a vertikális egyensúlytalanságot 2005-től felerősítette a központi kormányzat költségvetési szigorítása, amelynek keretében forrásokat vont el ettől az alrendszertől (is).

A központi ellenőrzés és transzparencia gyengesége tovább rontotta a helyzetet. Az elégtelen ellenőrzést részben jogszabályi kötöttségek is okozták. 2011-ig az Állami Számvevőszék nem volt jogosult az önkormányzati tulajdonban lévő vállalatok ellenőrzésére. A spanyol tapasztalatokhoz hasonlóan a magyar önkormányzatok tulajdonában álló vállalkozások is alkalmasak voltak a költségvetési hiány költségvetésen kívülre helyezésére.

A magyar tapasztalatok azt mutatják, hogy a jelentős központi (uniós és tagállami) fejlesztési támogatások, ha nem átgondolt fejlesztési politika keretében használják fel őket, hosszú távon a szándékolttal ellentétes hatást válthatnak ki: gyengíthetik a helyi költségvetési stabilitást.

Magyarországon az önkormányzatok a meglévő jogszabályokat is kijátszva a közbeszerzés alá tartozó hitelfelvétel helyett a közbeszerzés nélküli kötvénykibocsátást részesítették előnyben a válságot közvetlenül megelőző két évben. A forrásbevonás mögött jelentős részben spekulatív célok álltak, nem konkrét fejlesztési igények. A magyar önkormányzatok hosszú lejáratú alacsony kamatozású deviza- (többségében svájcifrank-) forrást vontak be, amit rövid távú, magasabb kamatozású forinteszközökbe fektettek be - gyakorlatilag úgynevezett carry trade pozíciót építettek fel. A szakirodalom a regionális és a helyi önkormányzatok esetében a fedezetlen devizahitelezést mint jelentős kockázatot nem emeli ki. A magyar önkormányzati szektor költségvetési válságában azonban ennek a tényezőnek kulcsszerepe volt.

A magyar kormány egy sajátos eszközrendszerrel több lépésben kitisztította az önkormányzati kör pénzügyi mérlegét, megszüntetve ezzel jelentős nyitott devizapozíciójukat: a konszolidáció során átvállalt teljes adósságállomány a 2014. évi GDP 4,2 százalékát tette ki.

A költségvetési konszolidáció a rendkívüli költségvetési támogatás mellett újszerű technikákat is tartalmazott. Az adósságokat a következő eljárásokkal vállalta át a központi kormányzat: jelentősebb feladatátvállalás okozta teljes körű és általános jogutódlással, valamint háromoldalú (állam, önkormányzatok és bankok részvételével megkötött) szerződések alapján a felek az eredeti kötelezettségek valamennyi jogra és kötelezettségre kiterjedő engedményezéssel és tartozásátvállalással a teljes szerződéses pozíció jogutódlásában állapodtak meg. A devizaátvállalások az Államadósság Kezelő Központhoz, míg a forintkötelezettségek a Magyar Államkincstárhoz kerültek. A nemzetközi gyakorlattal összhangban a központi pénzügyi segítségnyújtás Magyarországon is együtt járt költségvetési fegyelmező eszközök alkalmazásával és a költségvetési transzparenciára, illetve adatszolgáltatásra vonatkozó követelmények erősítésével. Ezek közül kiemelendő az új adósságok esetében a központi engedélyezési rendszer kialakítása, valamint a működési költségvetést illetően a hiány tervezésének a tiltása. Véleményünk szerint ilyen szabályok nélkül 
az önkormányzatok pénzügyi stabilitása, illetve annak fenntarthatósága hosszú távon nem lenne biztosítható.

További kutatási kérdésként adódik, hogy az új önkormányzati gazdálkodási rendszerben felpuhul-e a költségvetési korlát, és gyakoribbá válik-e az egyes önkormányzatok eseti kimentése, vagy ellenkezőleg: a bevezetett költségvetési fegyelmező eszközök miatt a konszolidáció egy egyszeri kimentés volt.

\section{Hivatkozások}

ÁSZ [2012]: Összegzés a helyi önkormányzatok pénzügyi helyzetének és gazdálkodási rendszerének 2011. évi ellenőrzéseiről. Az Állami Számvevőszék 1282. jelentése. https://www.asz.hu/ storage/files/files/\%C3\%96sszes\%20jelent\%C3\%A9s/2012/1282j000.pdf?ctid=728.

Beck, R.-Ferrucci, G.-Hantzsche, A.-Rau-Goehring, M. [2016]: Determinants of sub-sovereign bond yield spreads. The role of fiscal fundamentals and federal bailout expectations. ECB Working Paper Series, No. 1987.

Bethlendi, A. [2018]: Sovereign defaults and how to handle them. Global economic order vs. national economic policy interests - the examples of Greece, Hungary and Ukraine. Civic Review, Vol. 14. Különszám, https://doi.org/10.24307/psz.2018.0407.

Bolívar, M. P. R.-Galera, A. N.-Muñoz, L. A.-Subires, M. D. L. [2016]: Analyzing Forces to the Financial Contribution of Local Governments to Sustainable Development. Sustainability, Vol. 8. No. 9. 925-943. o. https://doi.org/10.3390/su8090925.

Canuto, O.-Liu, L. [2010]: Subnational Debt Finance: Make It Sustainable. World Bank. http://siteresources.worldbank.org/INTDEBTDEPT/Resources/468980-1207588563500/ 4864698-1207775351512/SubDebtFinance201009.pdf.

Cordes, T.-Guerguil, M.-Jaramillo, L.-Moreno-Badia, M.-Ylaoutinen, S. [2015]: Subnational Fiscal Crises. Megjelent: Cottarelli, C.-Guerguil, M. (szerk.): Designing a European Fiscal Union: Lessons from the Experience of Fiscal Federations. Routledge, LondonNew York.

GYiRÁN ZoLTáN [2016]: Adósságkezelés, adósságrendezés az önkormányzati pénzügyekben. Doktori értekezés. Debreceni Egyetem, Debrecen. https://dea.lib.unideb.hu/dea/bitstream/ handle/2437/227430/GyiranZoltan_ertekezes_titkositott.pdf?sequence=1\&isAllowed=y.

Hagen, von J.-Bordignon, M.-Grewal, B. S.-Peterson, P.-Seitz, H.-Dahlberg, M. [2000]: Subnational Government Bailouts in OECD Countries: Four Case Studies. Research Department Publications from Inter-American Development Bank, No. 3100. https://ideas. repec.org/p/idb/wpaper/3100.html.

Hegedüs József-Tönkö Andrea [2006]: Az önkormányzati gazdasági társaságok szerepe a helyi önkormányzatok vagyongazdálkodásában: a feltételes kötelezettségvállalás („contingent liability”) problémája. Megjelent: Vigvári András (szerk.): A családi ezüst. Tanulmányok az önkormányzati vagyongazdálkodás témaköréből. Közigazgatási olvasmányok. Complex Kiadó, Budapest, 67-94. o.

Homolya DÁnIEL-Szigel GÁbor [2008]: Önkormányzati hitelezés - kockázatok és banki viselkedés. MNB Szemle, szeptember, 20-29. o. https://www.mnb.hu/letoltes/homolyadaniel-szigel-gabor.pdf.

IMF [2013]: Sovereign debt restructuring - recent developments and implications for the Fund's legal and policy framework. International Monetary Fund, https://www.imf.org/ external/np/pp/eng/2013/042613.pdf. 
Jenkner, E.-Lu, Z. [2014]: Sub-National Credit Risk and Sovereign Bailouts. Who Pays the Premium? IMF Working Paper, No. 20.

Kornai János [2014]: A puha költségvetési korlát. Kalligram Kiadó, Pozsony.

Lentner Csaba [2014]: The Debt Consolidation of Hungarian Local Governments. Public Finance Quarterly, Vol. 59. No. 3. 310-325. o.

LiU, L.-WAibel, M. [2009]: Subnational insolvency and governance: cross-country experiences and lessons. Megjelent: Ahmad, E.-Brosio, G. (szerk.): Does Decentralization Enhance Service Delivery and Poverty Reduction? Edward Elgar Publishing Limited, Cheltenham, UK-Northampton, MA, 333-375. o. http://siteresources.worldbank.org/INTDEBTDEPT/ Resources/468980-1207588563500/4864698-1207775351512/PRWP4496_02.pdf.

Minályi PÉTer [2012]: Elitváltás, centralizáció és a települési önkormányzatok jogainak csorbítása az egészségügyben. Fundamentum, Fórum, 2. sz. http://fundamentum.hu/sites/ default/files/teljes-szamok/fundamentum-12-2-beliv.pdf.

Seitz, H. [2000]: Fiscal policy, deficits, and politics of subnational governments: The case of the German Länder. Public Choice, Vol. 102. No. 3-4. 183-218. o. https://doi. org/10.1023/a:1005000124300.

Vicente Lama, De M.-Cordobés Madueño, M.-Torres Jiménez, M. [2017]: To what extent should public corporations be consolidated? Considering the effects on public deficit and debt in Spanish municipalities. Transylvanian Review of Administrative Sciences, No. 52. 148-164. o. https://doi.org/10.24193/tras.52E.9.

VigVÁRi ANDRÁs [2009]: Atipikus önkormányzati eladósodás Magyarországon. Közgazdasági Szemle, 56. évf. 7-8. sz. 709-730. o.

VIGVÁRI ANDRÁs [2010]: Is the conflict container full? Problems of fiscal sustainability at the local government level in Hungary. Acta Oeconomica, Vol. 60. No. 1. 49-77. o. https://doi. org/10.1556/aoecon.60.2010.1.4. 